\title{
Pengaruh Sistem Pelaporan dan Kejelasan Sasaran Anggaran Terhadap Akuntanbilitas Kinerja Instansi Pemerintah (Studi Pada Satuan Kerja Pemerintah Aceh)
}

\author{
Mulyadi $\mathrm{AR}^{1}$, Syamsidar $^{2}$, Dedy Efendy ${ }^{2}$ \\ ${ }^{1,2,3}$ Fakultas Ekonomi Universitas Muhammadiyah Aceh
}

\begin{abstract}
This research aims to determine the effect of the reporting system and the clarity of the budget target on the accountability of the performance of Aceh Government Agencies, the formulation of the problem in this study is whether there is an effect on the reporting system and clarity of budget targets on the accountability of Aceh Government performance both simultaneously and partially.

Data collection uses a questionnaire, and is analyzed qualitatively and converted into quantitative data using a Likert Scale. Data analysts to see the effect of dependent variables with independent variables using analysis of multiple linear regression equations.

The population of this study amounted to 84 respondents, who were examined by the Head of Section (Head of Section) and Head of Division (Head) in Aceh Government Agencies. The results of the study found that the reporting system and the clarity of budget targets simultaneously had a significant effect on the performance of the Aceh Government. The partial reporting system has a significant effect on the accountability of the performance of Aceh Government Agencies. Clarity of budget targets partially has a significant effect on the accountability of the performance of Aceh Government Agencies. The reporting system has more dominant influence on the accountability of the performance of Aceh Government Agencies. It is expected that in the future the Aceh Government will pay more attention to the clarity of the budget goals in budgeting, because the results of the research regression coefficients have the smallest effect on the accountability of the performance of Aceh Government agencies in clarity of budget targets, with the hope that these variables will have greater influence on the accountability of Agency performance The Aceh Government in the future.
\end{abstract}

Keywords : Reporting system, clarity of budget targets and accountability

Abstrak

Penelitiaan ini bertujuan untuk mengetahui pengaruh sistem pelaporan dan kejelasan sasaran anggaran terhadap akuntanbilitas kinerja Instansi Pemerintah Aceh, rumusan masalah pada penelitian ini yaitu apakah ada pengaruhnya sistem pelaporan dan kejelasan sasaran anggaran terhadap akuntanbilitas kinerja Pemerintah Aceh baik secara simultan maupun secara parsial.

Pengumpulan data menggunakan kuesioner, dan di analisa secara kualitatif dan dikonversikan terlebih dahulu menjadi data kuantitatif dengan menggunakan Skala Likert. Analis data untuk melihat pengaruh variabel terikat dengan variabel bebas menggunakan analisis persamaan regresi linear berganda.

Populasi penelitian ini berjumlah sebanyak 84 responden, yang diteliti Kepala Bagian (Kabag) dan Kepala Bidang (Kabid) di Instansi Pemerintah Aceh. Hasil penelitian diperoleh bahwa sistem pelaporan dan kejelasan sasaran anggaran secara simultan berpengaruh signifikan terhadap kinerja Pemerintah Aceh. Sistem pelaporan secara parsial berpengaruh signifikan terhadap akuntabilitas kinerja Instansi Pemerintah Aceh. Kejelasan sasaran anggaran secara parsial berpengaruh signifikan terhadap akuntabilitas kinerja Instansi Pemerintah Aceh. Sistem pelaporan lebih dominan pengaruhnya terhadap akuntabilitas kinerja Instansi Pemerintah Aceh. Diharapkan kepada Pemerintahan Aceh dimasa yang akan datang supaya lebih memperhatikan kejelasan sasaran anggaran dalam penyusunan anggaran, karena dari hasil penelitian koefisien regresi yang paling kecil pengaruhnya terhadap akuntabilitas kinerja Instansi Pemerintah Aceh kejelasan sasaran anggaran, dengan harapan variabel ini akan berpengaruh lebih besar terhadap akuntabilitas kinerja Instansi Pemerintah Aceh di masa yang akan datang.

Kata Kunci: Sistem pelaporan, kejelasan sasaran anggaran dan Akuntanbilitas

\section{PENDAHULUAN}

Kemajuan pemerintahan dalam bidang politik dan reformasi menyebabkan pemerintah mengganti sistem politik otoriter masa lalu dengan sistem demokrasi. Kenyataannya di dalam laporan keuangan pemerintah, masih banyak disajikan data yang tidak sesuai yang berhasil ditemukan oleh Badan Pemeriksa Keuangan (BPK). Untuk menegakkan akuntabilitas khususnya pada kinerja di daerah, pemerintah daerah bertanggungjawab 
untuk mempublikasikan laporan keuangan kepada pemangku kepentingannya.

Fenomena yang terkait dengan akuntabilitas kinerja yaitu masih rendahnya akuntabilitas kinerja baik ditingkat nasional maupun daerah memunculkan masalah pengelolaan keuangan daerah yang buruk, untuk menghindari permasalahan seperti yang diketahui maka Pemerintah Aceh khususnya aparatur pemerintah daerah harus meningkatkan kinerja dan akuntabilitas demi terwujudnya good governance atau yang biasa disebut dengan pemerintahan yang baik sehingga mampu menyediakan public good dan public service untuk masyarakat dan juga pemerintah daerah harus membenahi diri untuk melakukan perubahan yang diinginkan oleh masyarakat (Nurhalimah, 2013).

Fenomena yang masih sering terjadi selama ini di Pemerintah Aceh yaitu masih seringnya terjadi keterlambatan dalam sistem pelaporan sehingga proses untuk merealisasikan anggaran menjadi terhambat yang pada akhirnya beperngaruh terhadap rendahnya kinerja. Proses penyusunan laporan keuangan masih belum begitu baik. Hal ini terjadi karena masih banyaknya pengelola keuangan yang tidak memiliki pengetahuan dalam bidang keuangan. Sesuai dengan hasil review Inspektorat Pemerintah Aceh pada tahun 2014 kurangnya kualitas laporan keuangan yang ada dikarenakan masih kurangnya tenaga di bidang akuntansi yang menjabat sebagai PPK-SKPD.

Berdasarkan hasil amatan publik yang pernah disampaikan oleh Masyarakat Transparansi Aceh (MaTA) sampai dengan bulan November 2014 tercatat dari 39 SKPA di Pemerintah Aceh yang realisasi keuangan masih dalam kategori merah ada sebanyak 18 SKPA. Sedangkan untuk kategori kuning sebanyak 12 SKPA, hijau sebanyak 10 SKPA, dan biru sembilan SKPA. Daya serap anggaran maupun realisasi fisik, kinerja Pemerintah Aceh masih cukup buruk. Hal ini memberikan indikasi bahwa dari realisasi dan perencanaan anggaran yang terpaut jauh, karena masa anggaran 2014 hanya satu bulan. Jika tidak terealiasi seratus persen hingga akhir Desember berarti kinerja Pemerintah tidak lebih baik dari sebelumnya. Realisasi Anggaran Pendapatan dan Belanja Aceh (APBA) tahun 2014 masih sangat rendah. Hingga 6 November 2014 realisasi keuangan baru mencapai $60,3 \%$ dan realisasi fisik $65 \%$ dari total APBA, perubahan 2014 yakni sebesar Rp12,9 triliun. Meskipun pengesahan anggaran 2014 lebih cepat dari tahun-tahun sebelumnya, tapi serapan anggaran Pemerintah Aceh masih sangat rendah. (http://www.acehnews.net/mata-catat18-skpa-dipemerintah-aceh-berapor-merah)

Berdasarkan perhitungan dan analisis kinerja Pemerintah Provinsi Aceh yang dilakukan dengan cara membandingkan antara rencana kinerja dengan tingkat realisasi, ternyata tingkat capaian kinerja atas kegiatan dan sasaran yang telah ditetapkan oleh Pemerintah Provinsi Aceh seperti yang diamati dan di tulis oleh MATA, sangat jelas tidak diperoleh angka capaian di luar perencanaan. sehingga menyebabkan tingkat kecenderungan dalam melakukan penilaian / pengukuran kinerja menjadi bias atau kurang objektif. Dengan demikian, daya serap anggaran maupun realisasi fisik, kinerja pemerintah Aceh masih cukup buruk. Ini jelas terlihat, dari realisasi dan perencanaan anggaran yang terpaut jauh. Sebagaimana diketahui, seperti pada masa anggaran 2015 ini hanya satu bulan setengah lagi. Ini artinya pemerintah Aceh harus bekerja ekstra untuk merealisasikan anggaran setiap tahunnya supaya lebih cepat.

Penelitian ini merupakan replikasi dari penelitian yang dilakukan oleh Setiawan (2013), dimana hasil penelitiannya disebutkan bahwa kejelasan sasaran anggaran berpengaruh signifikan terhadap akuntabilitas kinerja instansi pemerintah. Pengendalian akuntansi berpengaruh signifikan terhadap akuntabilitas kinerja instansi pemerintah. Sistem pelaporan tidak berpengaruh terhadap akuntabilitas kinerja instansi pemerintah. Perbedaan antara penelitian ini dengan penelitian Setiawan (2013) adalah dalam penelitian sekarang peneliti tidak menggunakan variabel pengendalian akuntansi, sementara persamaannya adalah samasama menggunakan variabel sasaran anggaran, sistem pelaporan dan akuntabilitas kinerja. Obyek penelitian dan alat analisis yang digunakan juga berbeda, selain itu pendekatan penelitian yang digunakan dalam penelitian ini adalah pendekatan kuantitatif, untuk mendapatkan pengayaan pemahaman yang lebih mendalam di balik pengaruh sistem pelaporan dan kejelasan tujuan anggaran terhadap akuntabilitas kinerja Pemerintah Aceh. Dari latar belakang yang telah dipaparkan di atas maka penulis tertarik untuk membuat penelitian yang dituangkan dalam sebuah karya ilmiah dengan judul "Pengaruh Sistem Pelaporan dan Kejelasan Sasaran Anggaran Terhadap Akuntanbilitas Kinerja Instansi Pemerintah (Studi Pada Satuan Kerja Pemerintah Aceh)".

\section{KAJIAN LITERATUR}

\section{Akuntabilitas Kinerja Pemerintah}

Akuntabilitas adalah kewajiban untuk memberikan pertanggung jawaban atau untuk menjawab dan menerangkan kinerja dan tindakan seseorang / badan / hukum / pimpinan kolektif suatu organisasi kepada pihak yang memiliki hak atau berkewenangan untuk menerima keterangan atau pertanggungjawaban. Menurut Mardiasmo (2012:21) akuntabilitas merupakan konsep yang lebih luas dari stewardship. Stewardship mengacu pada pengelolaan atas suatu aktivitas secara ekonomis dan efisien tanpa dibebani kewajiban untuk melaporkan, sedangkan akuntabilitas 
mengacu pada pertanggungjawaban oleh seorang steward kepada pemberi tanggung jawab.

Setiap Instansi Pemerintah, Badan dan Lembaga Negara di Pusat dan Daerah sesuai dengan tugas pokok masing-masing harus memahami lingkup akuntabilitasnya masingmasing, karena akuntabilitas yang diminta meliputi keberhasilan dan juga kegagalan pelaksanaan misi Instansi yang bersangkutan. (LAN RI dan BPKP, 2013: 43)

\section{Kinerja}

Kinerja menurut Mathoney (2014:116) kinerja merupakan penilaian seseoran atau individu (manajer) dalam pencapaian pelaksana kegiatan yang telah dilakukan. Penilaian kinerja adalah proses dimana organisasi mengevaluasi/menilai kinerja karyawan. Kegiatan ini dapat memperbaiki keputusan-keputusan personalia dan memberikan umpan balik kepada para karyawan tentang kinerja mereka (Handoko, 2014:171).

Suprihanto (2012) penilaian kinerja adalah suatu sistem yang digunakan untuk menilai dan mengetahui apakah seseorang telah melaksanakan pekerjaan masing-masing secara keseluruhan atau suatu proses yang terjadi di dalam organisasi menilai atau mengetahui kinerja seseorang. Glueck (2013) mendefinikan evaluasi kinerja sebagai kegiatan penentuan sampai pada tingkat mana seseorang melaksanakan tugasnya secara efektif.

\section{Kejelasan Tujuan Anggaran}

Abdullah (2012) dan Nuraini dan Indudewi (2012) mengungkapkan bahwa kejelasan sasaran anggaran, pengendalian akuntansi, dan sistem pelaporan seluruhnya berpengaruh terhadap AKIP. Singkatnya waktu pembahasan anggaran instansi Pemerintah menyulitkan pembuat kebijakan untuk menjalankan fungsi anggaran secara maksimal, sehingga rentan terjadi kesalahan, ketidaktepatan sasaran, dan hanya mengacu pada program tahun sebelumnya yang tidak konstektual dengan kebutuhan mendatang. Pengukuran capaian kinerja dalam (Laporan Akuntabilitas Kinerja Instansi Pemerintah) LAKIP dilakukan dengan metode Performance Gap, yang dilaksanakan dengan membandingkan antara rencana kerja dengan capaian masing-masing kegiatan meliputi input, output, outcome, benefit, dan impact yang dilakukan melalui suatu proses sistematis dan berkesinambungan untuk menilai tingkat keberhasilan maupun kegagalan suatu program dan kegiatan, namun pengukuran indikator benefit dan impact relatif sulit dilaksanakan.

\section{Sistem Pelaporan}

Menurut Bastian (2010 : 297) "pelaporan kinerja merupakan refleksi kewajiban untuk mempresentasikan dan melaporkan kinerja semua aktivitas serta sumber daya yang harus dipertanggungjawabkan. Pelaporan ini merupakan wujud dari proses akuntabilitas kinerja". Setiap instansi pemerintah berkewajiban untuk menyiapkan, menyusun, dan melaporkan laporan keuangan secara tertulis, periodik dan melembaga. Laporan keuangan isntansi pemerintah merupakan representasi posisi keuangan dari transaksitransaksi yang dilakukan oleh instansi pemerintah.

Pelaporan kinerja dimaksudkan untuk mengkomunikasikan capaian kinerja instansi pemerintah dalam suatu tahun anggaran yang dikaitkan dengan proses pencapaian tujuan dan sasaran instansi pemerintah. Pelaporan kinerja oleh instansi pemerintah ini dituangkan dalam dokumen Laporan Akuntabilitas Kinerja Instansi Pemerintah (LAKIP).

\section{Kejelasan Sasaran Anggaran}

Kejelasan sasaran anggaran merupakan sejauh mana tujuan anggaran ditetapkan secara jelas dan spesifik dengan tujuan agar anggaran tersebut dapat dimengerti oleh orang yang bertanggung jawab atas pencapaian sasaran anggaran tersebut (Suharono dan Solichin, 2011). Pengelolaan keuangan pemerintahan daerah yang berakuntabilitas tidak lepas dari anggaran pemerintah daerah. Hal ini sesuai dengan pendapat Mardiasmo (2012) yang menyatakan wujud dari penyelenggaraan otonomi daerah adalah manfaat sumber daya yang dilakukan secara ekonomis, efisien, efektif, adil dan merata untuk mencapai akuntabilitas publik. Anggaran diperlukan dalam pengelolaan sumber daya tersebut dengan baik untuk mencapai kinerja yang diharapkan oleh masyarakat dan menciptakan akuntabilitas terhadap masyarakat.

\section{Kerangka Pemikiran}

\section{Hubungan Sistem Pelaporan dengan} Akuntanbilitas Kinerja Instansi Pemerintah

Sistem pelaporan yang baik diperlukan agar dapat memantau dan mengendalikan kinerja manajerial dalam mengimplementasikan anggaran yang telah ditetapkan. Laporan umpan balik (feedback) diperlukan untuk mengukur aktivitas aktivitas yang dilaksanakan dalam rangka meningkatkan kinerja dan akuntabilitas pada pelaksanan suatu rencana atau waktu mengimplementasikan suat anggaran, sehingga manajeman dapat mengetahui hasil dari pelaksanaan rencana atau pencapaian sasaran anggaran yang ditetapkan. Pemerintah daerah selaku pengelola dana publik harus mampu menyediakan informasi keuangan yang diperlukan secar akurat, relevan, tepat waktu, konsisten dan dapat dipercaya. Kusumaningrum, (2010) mengatakan bahwa terdapat hubungan dan pengaruh yang kuat antara sistem pelaporan dengan AKIP, hal ini memberikan gambaran bahwa semakin cepat sistem pelaporan maka semakin tinggi akuntabilitas kinerja pemerintah dan 
sebaliknya semakin rendah sistem pelaporan maka akan semakin rendah akuntabilitas kinerja pemerintah.

\section{Hubungan Kejelasan Sasaran Anggaran dengan Akuntanbilitas Kinerja Instansi Pemerintah}

Kejelasan sasaran anggaran menunjukkan luasnya tujuan anggaran yang dinyatakan secara spesifik, jelas, dan dimengerti oleh siapa saja yang bertanggungjawab. Kennis (2011: 201) menemukan bahwa manajer memberi reaksi positif dan secara relatif sangat kuat untuk meningkatkan kejelasan sasaran anggaran. Manajemen tingkat atas dapat meningkatkan kepuasan kerja, menurunkan ketegangan kerja, dan memperbaiki anggaran yang dihubungkan dengan sikap, kinerja anggaran, dan efisiensi biaya manajer tingkat bawah secara signifikan meningkatkan kejelasan dan ketegasan sasaran anggaran mereka.

Berdasarkan bebera teori yang telah dikemukakan diatas dapat dismpulkan bahwa kejelasan sasran anggaran dan sistem pelaporan berpengaruh terhadap kinerja. Skema kerangka pemikiran penelitian ini dapat dilihat pada Gambar 2.1 .

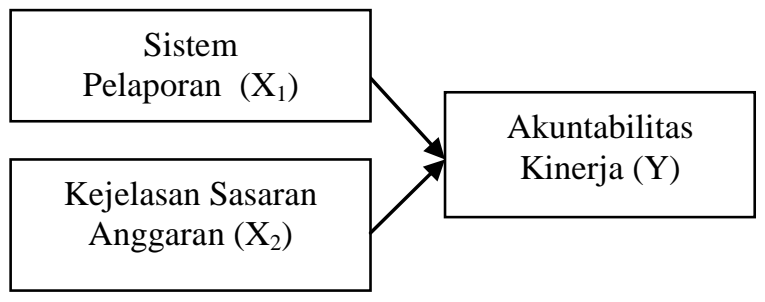

\section{Gambar 2.1}

Hipotesis

\section{Skema Paradigma}

Hipotesis merupakan suatu anggapan sementara yang akan dibuktikan kebenarannya dalam suatu penelitian. Berdasarkan kerangka pemikiran yang telah dikemukakan sebelumnya, dapat dinyatakan hipotesis statistik yaitu:

Ha1 : Sistem pelaporan dan kejelasan sasaran anggaran secara simultan berpengaruh terhadap akuntabilitas kinerja Pemerintah Aceh.

Ha2 : Sistem pelaporan secara parsial berpengaruh terhadap akuntabilitas kinerja Pemerintah Aceh.

Ha3 : Kejelasan sasaran anggaran secara parsial berpengaruh terhadap akuntabilitas kinerja Pemerintah Aceh.

\section{METODE PENELITIAN}

\section{Populasi Penelitian}

Populasi dalam wilayah generalisasi yang terdiri atas obyek/subyek yang mempunyai kualitas dan karakteristik tertentu yang ditetapkan oleh peneliti untuk dipelajari dan kemudian ditarik kesimpulannya (Sugiono, 2013). Mengingat keterbatasan waktu dan tenaga serta biaya, penulis membatasi responden yang diteliti hanya Kepala Bagian (Kabag) dan Kepala Bidang (Kabid). Oleh karena itu populasi dalam penelitian ini saat ini berjumlah sebanyak 84 responden.

\section{Metode Analisis}

Pada penelitian ini pendekatan analisis yang dilakukan dengan metode Ordinary Least Square (OLS). Metode OLS bertujuan untuk mengestimasi suatu garis regresi dengan jalan meminimalkan jumlah dari kuadrat kesalahan setiap observasi terhadap garis tersebut. Dari kerangka konsep dan operasional variabel sebagaimana telah dikemukakan sebelumnya, digunakan model Regresi Linear berganda dengan persamaan sebagai berikut:

Keterangan:

$\begin{array}{ll}\mathrm{Y} & =\text { Akuntabilitas Kinerja Pemerintah } \\ \alpha & =\text { Konstanta } \\ \beta_{1}, \beta_{2}, \beta_{3} & =\text { Koefisien regresi } \\ \mathrm{X}_{1} & =\text { Sistem Pelaporan } \\ \mathrm{X}_{2} & =\text { Kejelasan Sasaran Anggran } \\ \varepsilon & =\text { Error Terms }\end{array}$

\section{Rancangan Pengujian Hipotesis}

Untuk menguji hipotesis pertama $\left(\mathrm{H}_{1}\right)$, yaitu pengaruh variabel independen secara bersama-sama terhadap variabel dependen, dilakukan langkahlangkah sebagai berikut:

1. Menentukan hipotesis nol $\left(\mathrm{H}_{0}\right)$ dan hipotesis alternatif $\left(\mathrm{H}_{\mathrm{a}}\right.$ Hipotesis pertama $\left(\mathrm{H}_{1}\right)$

$\mathrm{H}_{\mathrm{o} 1}: \beta_{\mathrm{i}}=0 \quad$ Tidak adanya pengaruh sistem pelaporan dan kejelasan sasaran anggaran secara bersama-sama terhadap akuntabilitas Kinerja Pemerintah Aceh.

$\mathrm{H}_{\mathrm{a} 1}: \beta_{\mathrm{i}} \neq 0$ Adanya pengaruh sistem pelaporan dan kejelasan sasaran anggaran secara bersama-sama terhadap akuntabilitas Kinerja Pemerintah Aceh.

2. Menentukan kriteria penerimaan dan penolakan hipotesis

Jika $\beta_{\mathrm{i}}(\mathrm{i}=1,2)=0 ; \mathrm{H}_{0}$ diterima artinya variabel independen secara simultan tidak mempengaruhi variabel dependen. Jika paling sedikit ada satu $\beta_{\mathrm{i}}(\mathrm{i}=1,2) \neq 0 ; \mathrm{H}_{0}$ ditolak artinya variabel independen sacara simultan mempengaruhi variabel dependen.

Untuk menguji pengaruh variabel independen secara parsial terhadap variabel dependen dilakukan langkah-langkah sebagai berikut : 
3. Menentukan hipotesis nol $\left(\mathrm{H}_{0}\right)$ dan hipotesis alternatif $\left(\mathrm{H}_{\mathrm{a}}\right)$.

Hipotesis kedua $\left(\mathrm{H}_{2}\right)$

$\mathrm{H}_{02:} \beta_{1}=0$; Tidak adanya pengaruh sistem pelaporan secara parsial terhadap akuntabilitas Kinerja Pemerintah Aceh.

$\mathrm{H}_{\mathrm{a} 2:} \beta_{1} \neq 0$; Adanya pengaruh sistem pelaporan secara parsial terhadap akuntabilitas Kinerja Pemerintah Aceh.

Hipotesis ketiga $\left(\mathrm{H}_{3}\right)$

$\mathrm{H}_{03}: \beta_{2}=0$; Tidak adanya pengaruh kejelasan sasaran anggaran secara parsial terhadap akuntabilitas Kinerja Pemerintah Aceh.

$\mathrm{H}_{\mathrm{a} 3}: \beta_{2} \neq 0 ;$ Adanya pengaruh kejelasan sasaran anggaran secara parsial terhadap akuntabilitas Kinerja Pemerintah Aceh.

4. Menentukan kriteria penerimaan dan penolakan hipotesis

Kriteria penerimaan dan penolakan hipotesis adalah sebagai berikut:

- $\quad$ Jika $\beta_{\mathrm{i}}(\mathrm{i}=1,2)=0: \mathrm{H}_{\mathrm{a}}$ tidak diterima

- $\quad$ Jika $\beta_{\mathrm{i}}(\mathrm{i}=1,2) \neq 0: \mathrm{H}_{\mathrm{a}}$ diterima

$\mathrm{H}_{0}$ diterima artinya variabel independen tidak berpengaruh terhadap variabel dependen, sedangkan $\mathrm{H}_{0}$ ditolak berarti variabel independen berpengaruh terhadap variabel dependen.

\section{HASIL PENELITIAN DAN PEMBAHASAN}

Analisis Pengaruh Sistem Pelaporan Dan Kejelasan Sasaran Anggaran Terhadap Akuntabilitas Kinerja Instansi SKPA Pemerintah Aceh Dalam Penyusunan Anggaran

Hasil uji simultan memperlihatkan bahwa sistem pelaporan dan kejelasan sasaran anggaran secara simultan berpengaruh signifikan terhadap akuntabilitas kinerja Instansi SKPA Pemerintah Aceh. Temuan ini sepeendapat dengan penelitian yang dilakukan oleh Kusumaningrum, (2010) dan Maryanti (2002) yang menyebutkan bahwa sistem pelaporan dan kejelasan sasaran anggaran secara simultan berpengaruh signifikan dan positif terhadap akuntabilitas kinerja Instansi SKPA Pemerintah Aceh. Apabila sistem pelaporan dan kejelasan sasaran anggaran meningkat maka akuntabilitas kinerja Instansi SKPA Pemerintah Aceh juga semakin meningkat dan begitu juga sebaliknya.

\section{Pengaruh Sistem Pelaporan Terhadap Akuntabilitas Kinerja Instansi SKPA Pemerintah Aceh Dalam Penyusunan Anggaran}

Dari hasil penelitian diperoleh bahwa sistem pelaporan secara parsial berpengaruh signifikan terhadap akuntabilitas kinerja Instansi SKPA Pemerintah Aceh. Sistem pelaporan yang baik diperlukan agar dapat memantau dan mengendalikan kinerja manajerial dalam mengimplementasikan anggaran yang telah ditetapkan. Laporan umpan balik (feedback) diperlukan untuk mengukur aktivitas aktivitas yang dilaksanakan dalam rangka meningkatkan kinerja dan akuntabilitas pada pelaksanan suatu rencana atau waktu mengimplementasikan suat anggaran, sehingga manajeman dapat mengetahui hasil dari pelaksanaan rencana atau pencapaian sasaran anggaran yang ditetapkan.

Temuan ini sesuai dengan Kusumaningrum, (2010) menyebutkan bahwa terdapat hubungan dan pengaruh kuat antara sistem pelaporan dengan AKIP, hal ini memberikan gambaran bahwa semakin cepat sistem pelaporan maka semakin tinggi akuntabilitas kinerja pemerintah dan sebaliknya semakin rendah sistem pelaporan maka akan semakin rendah akuntabilitas kinerja pemerintah. Pendapat lainnya juga sesuai dengan pendapat yang dikemukakan oleh LAN dan BPKB (2000) dalam Indudewi (2008) yaitu laporan yang baik adalah laporan harus disusun secara jujur, obyektif, dan transparan hal ini akan berpengaruh atau berdampak positif terhadap akuntabilitas kinerja pemerintah.

\section{Pengaruh Kejelasan Sasaran Anggaran Terhadap Akuntabilitas Kinerja Instansi SKPA Pemerintah Aceh dalam Penyusunan Anggaran}

Dari hasil penelitian diperoleh bahwa sistem pelaporan secara parsial berpengaruh signifikan terhadap akuntabilitas kinerja Instansi SKPA Pemerintah Aceh. Temuan ini sependapat dengan Kennis (2000: 201) mengatakan bahwa manajer memberi reaksi positif dan secara relatif sangat kuat untuk meningkatkan kejelasan sasaran anggaran. Manajemen tingkat atas dapat meningkatkan kepuasan kerja, menurunkan ketegangan kerja, dan memperbaiki anggaran yang dihubungkan dengan sikap, kinerja anggaran, dan efisiensi biaya manajer tingkat bawah secara signifikan meningkatkan kejelasan dan ketegasan sasaran anggaran mereka.

. Hal ini menunjukkan bahwa karakteristik tujuan anggaran secara keseluruhan menghasilkan pengaruh yang cukup kuat terhadap kinerja pemerintah dalam rencana penyusunan anggaran. Pendapat lainnya juga dikemukakan oleh Munawar (2006) bahwa kejelasan sasaran anggaran merupakan sejauh mana tujuan anggaran ditetapkan secara jelas dan spesifik dengan tujuan agar 
anggaran tersebut dapat dimengerti oleh orang yang bertanggung jawab atas pencapaian sasaran anggaran tersebut. Oleh sebab itu, sasaran anggaran daerah harus dinyatakan secara jelas, spesifik dan dapat dimengerti oleh mereka yang bertanggung jawab untuk menyusun dan melaksanakan kegiatan anggaran. Ketidakjelasan sasaran anggaran menjadi bingung, tidak tenang dan tidak puas dalam bekerja, implikasinya pada penurunan kinerja yang berarti juga penurunan akuntabilitas kinerja organisasi (Suhartono dan Mochammad, 2006).

\section{PENUTUP}

\section{Kesimpulan}

Berdasarkan hasil penelitian yang telah dilakukan maka dapat di ambil kesimpulan yaitu :

1. Sistem pelaporan dan kejelasan sasaran anggaran secara simultan berpengaruh signifikan terhadap akuntabilitas kinerja Pemerintah Aceh.

2. Sistem pelaporan secara parsial berpengaruh signifikan terhadap akuntabilitas kinerja Instansi Pemerintah Aceh.

3. Kejelasan sasaran anggaran secara parsial berpengaruh signifikan terhadap akuntabilitas kinerja Instansi Pemerintah Aceh.

Sistem pelaporan lebih dominan $60,70 \%$ dari kejelasan sasaran anggaran sebesar 38,70\% berpegaruhnya terhadap akuntabilitas kinerja Instansi Pemerintah Aceh.

\section{Saran}

1. Diharapkan kepada Pemerintahan Aceh dimasa yang akan datang supaya lebih memperhatikan kejelasan sasaran anggaran dalam penyusunan anggaran, karena dari hasil penelitian koefisien regresi yang paling kecil pengaruhnya terhadap akuntabilitas kinerja Instansi Pemerintah Aceh kejelasan sasaran anggaran, dengan harapan variabel ini akan berpengaruh lebih besar terhadap akuntabilitas kinerja Instansi Pemerintah Aceh di masa yang akan datang.

2. Dalam penyusunan anggaran diharuskan untuk menetapkan kejelasan sasaran anggaran yang dibutuhkan supaya anggaran dapat terdistribusi dengan baik pada berbagai dinas di Provinsi Aceh.

\section{DAFTAR PUSTAKA}

Abdullah, Hilmi. (2012). Pengaruh Kejelasan Sasaran Anggaran, Pengendalian Akuntansi, dan Sistem Pelaporan Terhadap Akuntabilitas Kinerja Instansi Pemerintah Daerah. Kompak No. 13, Januari-April 2012: 37-67.
Aimee, F.,dan Carol E., (2014). Aligning Priorities In Local Budgeting Processes. Journal of Public Budgeting, Accounting \& Financial Management. Vol. 16, No.2: 210-2018.

Akbar dan Nurbaya, (2011). Good Governance. Jakarta: LP3ES.

Bastian Indra (2015). Akuntansi Sektor Publik. Jakarta: Erlangga

Handoko, Hani, T, (2014). Personalia dan Sumber Daya Manusia. Yogyakarta: Liberty.

Haspiarti (2012), Pengaruh Penerapan Anggaran Berbasis Kinerja Terhadap Akuntabilitas Kinerja Instansi Pemerintah (Studi pada Pemerintah Kota Parepare). Jurnal Akuntansi Keuangan. Vol 3 No 4 : 41-51.

Herawati, Netty. (2011). Pengaruh Kejelasan Sasaran Anggaran, Pengendalian Akuntansi, dan Sistem Pelaporan terhadap Akuntabilitas Kinerja Instansi Pemerintah Daerah Kota Jambi. Jurnal Penelitian Universitas Jambi, (Online), Volume 13 No. 2.

Indudewi, Dian. (2012). "Pengaruh Kejelasan Sasaran Anggaran, Pengendalian Akuntansi dan Sistem Pelaporan terhadap AKIP Kabupaten Brebes". Skripsi. Universitas Semarang

Kerlinger, R. N. (2011). Foundations Of Behavioral Research (edisi 3). New York: Holt, Rinehart and Winston.

Kusumaningrum, Indraswari, (2010). Pengaruh Kejelasan Anggaran, Pengendalian Akuntansi dan Sistem Pelaporan terhadap Akuntabilitas kinerja Instansi Pemerintah Provinsi Jawa Tengah, Tesis Universitas Diponegoro.

LAN dan BPKP. (2013). Pedoman Penyusunan Pelaporan Akuntabilitas Kinerja Instansi Pemerintah. Jakarta: LAN dan BPKP

Lazzaro dan Brush (2013). Behavior Accounting, Cincinnati, Ohio: South Western Publishing Co.

Mahmudi, (2010). Akuntansi Sektor Publik di Indonesia. Yogyakarta: BPFE Yogyakarta.

Mardiasmo, (2012). Akuntansi Sektor Publik. Yogyakarta: Andi.

Maryanti, H., A., (2015)., Pengaruh Karakteristik Tujuan Anggaran Terhadap Perilaku, Sikap, dan Kinerja Pemerintah Daerah Di Propinsi Nusa Tenggara Timur. (Tesis). 
Masri, Singarimbun. (2011). Metode Penelitian Survey. Jakarta: LP3ES.

Maryanti, H., A., (2015), Pengaruh Karakteristik Tujuan Anggaran Terhadap Perilaku, Sikap, dan Kinerja Pemerintah Daerah Di Propinsi Nusa Tenggara Timur. (Tesis).

Mathoney, (2014). Penilaian Kinerja Sektor Pelayanan Publik. Yogyakarta: Universiti Press.

Mulyadi dan Setiawan (2013). Akuntansi Biaya; Penentuan Harga Pokok dan Pengendalian Biaya. Yogyakarta: BPFE UGM.

Munandar (2014) Akutansi Untuk Usahawan, Jakarta: Fakultas Ekonomi Indonesia.

Munawar (2013) Pengaruh Karakteristik Tujuan Anggaran Terhadap Perilaku, Sikap, Dan Kinerja Aparat Pemerintah Daerah Di Kabupaten Kupang. Simposium Nasional Akuntansi X.

Mulyadi dan Setiawan (2015). Akuntansi Biaya; Penentuan Harga Pokok dan Pengendalian Biaya.Yogyakarta: BPFE.

Mustafa. Edwin Nasution. (2010). Pengenalan Ekslusif Ekonomi Islam. Jakarta: Kencana Prenada Media Group, cet.III.

Nordiawan Dedi (2013). Akuntansi Pemerintahan Jakarta : Salemba Empat

Nordiawan Dedi (2011) Akuntansi Sektor Publik. Edisi 7. Jakarta: Salemba

Nuraini. Indudewi, D., I. (2012). Pengaruh Kejelasan Sasaran Anggaran, Pengendalian Akuntansi, Dan Sistem Pelaporan Terhadap Akuntabilitas Kinerja Instansi Pemerintah Kabupaten Brebes. Jurnal Solusi Vo. 11 No. 4 Oktober 2012, h. 63-77. Semarang.

Nurhalimah, Darwanis, dan Syukriy Abdullah. (2013) Pengaruh Partisipasi Penyusunan Anggaran Dan Kejelasan Sasaran Anggaran Terhadap Kinerja Aparatur Perangkat Daerah Di Pemerintah Aceh. Jurnal Akuntansi Pasca Sarjana Unsyiah.
Peraturan Pemerintah Republik Indonesia Nomor 58 Tahun 2005. Tentang Pengelolaan Keuangan Daerah. Lembaga Negara Republik Indonesia Tahun 2005 Nomor 40

Putra, Deki. (2013). Pengaruh Akuntabilitas Publik dan Kejelasan Sasaran Anggaran Terhadap Kinerja Manajerial Satuan Kerja Perangkat Daerah. Skripsi, Universitas Negeri Padang.

Sadjiarto (2011). Faktor-Faktor Yang Mempengaruhi Kinerja, Yogyakarta: Liberty.

Samryn (2013). Control in Organizations: Accounting and Human Behavior, Englewood Cliffs. Pretice Hall.

Sawitri Made, I Gusti Ayu Purnamawati, Nyoman Trisna Herawati (2015). Pengaruh Partisipasi Penyusunan Anggaran Terhadap Kinerja Manajerial Dengan Sistem Pengendalian Internal, Akuntabilitas Publik Dan Job Relevant Information Sebagai Variabel Pemoderasi (Studi Empiris Pada SKPD Kabupaten Bangli). E-Journal S1 Ak Universitas Pendidikan Ganesha Jurusan Akuntansi Program S1 (Volume 3 No. 1 Tahun 2015).

Sekaran, Uma. (2011). Research Method for Business, Metodologi Penelitian Untuk Bisnis. Edisi 4. Terjemahan Kwan Men Yon. Jakarta: Salemba Empat.

Setiawan (2013). Penilaian Kinerja. Jakarta: Erlangga.

Susilowati Harini (2014). Pengaruh Kejelasan Sasaran Anggaran, Pengendalian Akuntansi, Sistem Pelaporan, Dan Motivasi Kerja Terhadap Akuntabilitas Kinerja Pemerintah Daerah (Studi Kasus Pada Dinas Pemerintah Kota Surakarta). Artikel Publikasi Fakultas Ekonomi Dan Bisnis Program Studi Akuntansi Universitas Muhammadiyah Surakarta

Suhartono, Ehrmann; Solichin, Mochammad, (2011). "Pengaruh Kejelasan Sasaran Anggaran Terhadap Senjangan Anggaran Instansi Pemerintah Daerah dengan Komitmen Organisasi sebagai Pemoderasi”.SNA 9 Padang. 